\title{
Integration of Euro-Atlantic Norms and Values: Changes in the Military Culture of the Balkans
}

\author{
By Rajkovcevski Rade*
}

\section{Introduction}

In the recent past societies in the Balkan states have undergone profound changes during the period after the disintegration of Yugoslavia. The fragmentation of this previous regional power into a variety of successor states is the defining feature of the region. After the recent round of wars in the Balkans, the nations in the region imposed new roles and forms for their security forces, primarily in line with the requirements set forth in the NATO and EU enlargement processes.

Through the process of integration into Euro-Atlantic institutions, the Balkans were pushed to adopt many of the values of the "Western" world, primarily the achievement of democracy, rule of law, and independent political systems that are open to criticism and changes. Within these processes in the Balkans, the legitimate use of military force is also a serious issue, as it has a direct bearing on the region's stability. Recent achievements in the political penetrated deeply inside the military organizations, and were manifested through the behavior and actions of several nations' military forces. Additional challenges facing the region relate to the area of security sector reform, with particular relevance placed on the effort to promote the adoption of theories and practices of security affairs that are part of the programs of the Partnership for Peace and NATO.

An analysis of military culture in the region since the first civil war in Slovenia in 1991 to the latest armed conflict in Macedonia reflects that changes in the military cultures in the region have become deeply ingrained in the military staff. As a consequence of many events that had an impact on regional security, a military culture developed (in the shadow of a larger security culture) that has had a wide range of impact on the regions' military forces. In order to form a more objective opinion about military culture in the Balkans, it is important to draw a number of comparisons between the states in the region: type and level of social system, values, traditions, interests, as well as social-cultural similarities that decrease the likelihood of using military force to achieve political goals.

* Rajkovcevski Rade, M.Sc., is a Senior Fellow on the Faculty of Security Studies in Skopje, Macedonia. 
Current security trends in the Balkans are drawing the states deeper into security cooperation initiatives, which are in turn producing an environment of stability. States in the region are going to form a doctrine from the fact of peace, rather than pursuing peace based on a previous doctrine. With the emergence of a culture structured against extant security threats, countries are becoming more humane and predictable, and they forming a composite culture that can be deployed as a precisely calibrated instrument of national policy.

The manifestations of military culture could not be analyzed only from the perspective of internal relations within the armies. Therefore, views on military culture are also based on civil-military relations. With the reforms in the security sector, security forces started to abandon their formerly rigid relations within the military structure and with other parts of society. The new triangle arrangement between the state, army, and general public helps the army (through the Ministries of Defense in the new democracies) recruits the public, justify their activities, and gain more support in achieving their goals, both at home and abroad.

In addition, the changes in military culture have resulted from the participation of national forces in international missions as a part of NATO or Partnership of Peace operations. With these missions, the Balkan states have built a specific culture in the constantly strained security situation in the region by mixing with military cultures from the friendly countries involved in those missions. Developing a military culture that reflects the common military interests of the Balkan states should be a precondition for a successful security and defense policy.

\section{Military Culture of the Balkans}

Within the lexicon, ${ }^{1}$ the term culture (from the Latin colere, meaning to grow or to nurture) has numerous meanings. In the context of discussing military culture, we would single out for particular importance its meaning that is associated with development, education, training, enriching of spirit, and encouraging both professional and general education. Of additional importance are the aspects of the term that refer to the ethical progress of both the individual and the entire society to a level that represents the ideals of fairness, trustworthiness, humanity, and mutual respect.

Culture is the product of human behavior, values, traditions, habits, and everything that bears on social relations. It is a product of human consciousness, but its impact is not noticeable by individuals and social groups, who can be said more to inherit culture rather than create it.

Military culture is an example of the culture of groups that characterizes a profession or organization. In the context of the organization, culture leads to the so-called

\footnotetext{
Milan Vujaklija. Leksikon Stranih Reci i Izraza (Belgrade, Serbia: Prosveta, 1980), 485.
} 
collective programming of human behavior. Culture becomes visible by means of symbols, myths, rituals, and ceremonies; it is also manifested through stories, anecdotes, and legends. It encompasses the totality of constructed attitudes, norms, and values, and is often made apparent in such areas as: ${ }^{2}$

- Spirit of the "House" (philosophy of governance)

- Behavior in leadership and decision making

- Working mentality and working environment

- Informal and formal communication

- Pleasure in work

- Participation in the success of the service

Robert Cassidy writes, "Military culture comprises the beliefs and attitudes within a military organization that shape its collective preferences toward the use of force. These attitudes can impede or foster innovation and adaptation." 3 Military culture is created as a subtype of the general social culture mixed with such factors as geographical circumstances, mentality, military tradition, and historical events.

Military culture is a characteristic of the behavior of all members of the military organization, and covers all the norms of positive (i.e., professional) behavior. It reflects the behavior of the individual within the organization, and the behavior of the organization within the society. Military culture can be in conflict with the general culture within a nation (a disjunction that can be manifested by joking about military conduct and behavior on the part of the public). The norms governing military culture require respect for law and public order, respect for superiors, courage, precision, and self-sacrifice in dangerous situations, and it emphasizes both personal pride and the pride of the military organization.

2 Trpe Stojanovski. Policijata vo Demokratskoto Opshtestvo (Shtip, Macedonia: 2 August 1997), 276.

3 Robert M. Cassidy, "The British Army and Counterinsurgency: The Salience of Military Culture," Military Review 85:3 (2005); available at http://cgsc.contentdm.oclc. $\mathrm{org} / \mathrm{cgi}$-bin/showfile.exe?CISOROOT $=/ \mathrm{p} 124201$ coll1 \&CISOPTR $=171 \&$ filenam $\mathrm{e}=172$.pdf. 
THE QuARTERLY JOURNAL

The basic elements of military culture are: ${ }^{4}$

- Expectations and impact of the mission on family life

- Military acronyms and terms

- Chain of command

- Utilizing protocol

- Military customs and courtesies

- Transition issues

The features that describe military culture in detail are: relationship to management, adjustment to different situations and movements within the service, discipline, elitism within the organization, formality in internal communication, rigidity or inflexibility, interest in weapons and technology, distance from the public, militarism, resistance to accepting innovations related to training and technique, familial organization, the organization's loyalty to their employees and vice versa, physical predispositions that identify military members and make them identifiable in public, using symbols and styles of dress for both identification and markers of belonging, modesty in giving awards for successes, and unity.

The specific attributes of military culture in the Balkans have accumulated over years of history (particularly wars), and bear several characteristics of societies in transition. Additional attributes of typical Balkan military culture are blustering and exaggeration. They could be explained as meeting a need of self-actualization and obtaining benefits beyond the realm of soldiers' immediate circles of acquaintance.

Military culture comprises the ethos and professional attributes derived from both experience and intellectual study that contribute to military organizations' common understanding of the nature of war. Less easily studied than defined, its influence on military institutions is almost always the result of long-term factors that are rarely measurable, and are in fact often obscure both to historians and to those actually serving in the institutions - obscure, that is, until a war begins. ${ }^{5}$ No matter how intellectual structures are involved in defining a specific military culture, the decision to come to a clear definition can be questioned in several ways. First, it is something that is not empirically measurable, something that arises from the human subconscious; it is a result of acquired knowledge, experience, and work routine.

4 USDA Army Youth Development Project, ed., Operation: Military Kids Ready, Set, Go!, Training Manual, 3rd Edition, Chapter Four: Exploring Military Culture (April 2007), 8; available at http://esd113.org/uploads/documents/studentsupport/Children\%20of\%20 Military\%20Families/ReadySetGoManual/Chapter_4_Final.pdf.

5 Williamson Murray, "Military Culture Does Matter," FPRI Wire 7:2 (January 1999); available at http://www.fpri.org/fpriwire/0702.199901.murray.militaryculturedoesmatter.html. 
Second, a military culture that will actually be capable of overcoming the challenges posed by periods of conflict or war can only be implemented by members of the military organization, not by politicians who would hope to manipulate it.

\section{The Presence of Ideology in Military Culture}

Ideology might be described as an integrated and comprehensive set of views and opinions concerning the government, politics, public affairs, etc. Citizens or groups can declare their loyalty to one or another ideological position. Frequently, a shift of power in the Balkans will introduce a new ideology. In the last decades, communism, socialism, conservatism, liberalism, and populism have all been part of social and constitutional systems in the region. Ideology has a significant impact on military culture through the political views, attitudes, and opinions of the members of a given military. Every period crystallizes certain practices of action and behavior, as well as the types of social participation common among military forces.

Living in a militarized society or living with a choice to have a military career obviously represents a penetration of military culture into the broader culture and society. Using military vocabulary, terms, commands, and abbreviations has an impact on people who live in heavily militarized areas. Also, changes in the social values of militarized societies that are surrounded with conflict leaves durable influences on that society.

Subculture is an inherent part of any profession or interest group. The specific characteristics of military culture often result from the armed forces' hierarchical structure, which promotes the formation of shared attitudes and beliefs about both security-related and general issues among the majority of the members of the military. Holding similar shared views is a characteristic of members who are part of the same hierarchy scale within the horizontal structure of the military. The cohesion of military subculture is also affected by the time soldiers spend together during training and work, the frequency of dangerous and stressful situations that often threaten the lives of soldiers and their comrades, and many other features.

Examples of acts of collegiality in dangerous situations include saving the lives of colleagues and shared concealment of errors in work. In terms of the need to justify improper behavior on the part of the security forces, and due to the characteristics of the work that is done in the security sector, employees in the security forces often support the position that the rest of the population should view them as a victimized element of society, marooned on the margins of the larger culture, who are always prepare to sacrifice their lives for their country. This argument is often invoked to claim for them privileges beyond those held by other citizens, and to promote the right to engage in improper behavior when they fear that the state is imperiled, even when they engage in deception to cover for their colleagues and hide the truth. 
What then is the proper relationship between the military-established as a separate armed body in order to protect a society - and individual civilians, and the society in general? This relationship is articulated and enacted through what we have been calling "military culture." A constructive military culture is the result of the application of a theory of military performance balanced against the military's modern tasks in the areas of stability and peacekeeping. The basis of the answer comes from ancient times to the first beginnings of military organization in civilian societies. Regionally, in each Balkan country the answer to this question is deeply influenced by the individual nation's history, sentiments, mentality, and traditions. It depends on the role of the army as an armed public institution within the wider society. The determination is based on the perceptions of the public for of active military personnel, the prestige and social position of the military officer's profession, public opinion toward the state's defense and foreign policy, and the specific actions of the army, both at home and abroad. The nature of this triangle of elements is permanently changing because both society and the military are constantly changing as well, especially in the transitional countries, when it is obvious that a change of the whole political, social, and security system is under way.

The use of force is a particular symbol of all law enforcement and security institutions. By building a subculture that is based on internal relations and the existence of a collective subconscious that arises from the use of force and weapons, the armed forces are brought into a position that provides privileges and obligations in their work that distinguish them from other institutions of public administration. From the point of view of the state, the cohesiveness of the relationships within the military organization and authorized access to weapons can contribute to the demonstration of power by the military, and thus represent a threat to the state and its government.

Connections between the members of the military develop not only through their shared work, but also through informal relationships during leisure periods, which further promote the strengthening of a collective subculture. The complexity of relationships among members of the military organization is manifested through the creation of sponsorship, uniting the members of a military unit in a form of kinship ties between their families, swearing brotherhood and even the formation of partnerships for businesses outside the military. It speaks of a different dimension of military culture, one that can at times provide approval of the use of the military organization for illegal purposes. The number of members of a unit, their training to use force and weapons, the specialized abilities they have developed to work in specific conditions, knowledge of the psychology of the armed forces, and other factors may represent possible instruments for the realization of their goals. During the conflicts in the Balkans, many volunteers and mercenaries were taken into military organizations that later legalized their employment status within the armed forces. Their earlier behavior differed from the ethical codes and rules of service of the military organization, which 
put the Ministries of Defense of the Balkan countries to the test. They did not know whether to officially enlist these people (some of whom were former criminals) or, as part of the reform of the security sector, to establish new criteria for creating wholly new security and military forces, which would more rigorously screen applicants for military service.

The definition of the key elements of military culture has to be a product of the connection between the determinants of cultural identity and of the resulting culturally derived behaviors. That makes a distinction between behavioral consequences and the cultural inputs that shape them. Military culture is recognized for its distinctive attributes, especially by military personnel, their families, and veterans. However, military culture cannot avoid being influenced by the general culture. Many manifestations of military culture are in fact conscious reactions to the larger cultural environment that surrounds the members of military organization and their families. This cultural influence should be represented as a set of environmental beliefs (the parent's beliefs, friends and neighbors' beliefs, beliefs acquired through education and work, etc.). Individually, every member of the military may largely disagree with a certain opinion or way of thinking, but the building of attitudes within the collective or group includes other parameters on the creation of opinion. Also, the impact of military culture is not equal between beginners in the military and long-serving soldiers, or between enlistees who come from urban versus rural areas, because of the strong impact of family and local culture on military culture.

\section{Abuses of Military Culture in the Balkans}

The incidents that have surrounded the security forces in the Balkans show that its members went so far in taking advantage of their status in society and of the strong cohesion within security institutions that they have begun to enter into the organized crime. The essence of these activities is the generation of illegal profits through the abuse of privileges that the state provides to the members of the military. The connection between members of the military, police, and other law enforcement organizations with mafia circles has even led to the collapse of states in certain periods. This can be illustrated by a number of events: the assassination of Serbian Prime Minister Djindjic; various incidents related to war crimes in Bosnia and Herzegovina, Serbia, Croatia, and Kosovo; and others. With the stigmatization of individuals that are involved in illegal activities, the public image of the entire military organization suffers, since it is the public's money that funds the military budget.

The most destructive and dangerous incidents during the conflicts in the Balkans showed the results of the combined use of military skill and politics, embodied by figures who represented both variants-i.e., senior military officials who went into political life. Their knowledge of military psychology and of the structure of the military 
organization made it easier for them to achieve their political goals by using military force. In many states during this conflict period, members of the military were the only instruments of the power of repression, genocide, and exploitation. Members of the military that have already experienced the "smell of gunpowder," or were in the vicinity of battle, have different views about the value of peace and security in their native country and the region.

\section{Security Sector Reform}

The evolution of military culture in the Balkans came through security sector reform. Among the many changes in the social system during the post-communist transition, one of the most remarkable related to the opening up of the relationship between the military and the public.

As was the case everywhere, the military realm in the Balkans was considered to be a specific environment that was quite closed to the public, and that was based on its own internal values of hierarchical relations and communication between members. Described as conservative and deaf to criticism from the general and expert public, the armed forces needed to change their very nature, as well as to reform their internal relations and external interactions with society. The principal areas of the fundamental security concept related to creating a preventive and complex military culture are: strategic studies, military theory, national foreign policies, and international politics.

During the last decade, with the increase of civilian criticism of military activities and the rise in public involvement, there was a remarkable evolution of the democratic use of force by the military and law enforcement institutions in the Balkans. Almost every country in the region, either through its participation in NATO or through Partnership status with the Alliance, made an effort to create a contemporary vision for its military and integrate it into its national security policies. Also, as a part of the wider security sector reforms that deals with the development of democratic civilmilitary relations and defense planning, the essential trend arose tending toward the standardization of the countries of South-Eastern Europe with the rest of Europe.

During the period of security sector reform in Balkans, the security system was entirely recreated, and the large number of new civilians employed in the sector was a consequence of the use of incorrect tactics on the part of the political elite, which made an effort to employ more staff than were actually needed. Hiring criteria were disregarded, and there was significant political influence on the selection process. In such cases we cannot speak about the traditions of military culture, because the states were forced to rebuild a new military culture based on the quantity and diversity of new employees. In the Balkans, accepting some elements of foreign influence in certain phases of the Euro-Atlantic integration process does not mean that the Balkan states cannot keep their own authentic strategic culture. 


\title{
Relations Between Military Culture and Other Social Pheno- mena
}

\author{
Military Culture and Strategic Culture
}

A frequently used synonym of the term "military culture" is "strategic culture." Ken Booth describes strategic culture as a concept that "refers to a nation's traditions, values, attitudes, patterns of behavior, habits, symbols, achievements and particular ways of adapting to the environment and solving problems with respect to the threat or use of force." ${ }^{\prime}$ Strategic culture represents a set of shared beliefs, assumptions, and modes of behavior that are derived from common experiences and accepted narratives (both oral and written) that shape collective identity and relationships to other groups, and that determine the appropriate means for achieving security objectives. ${ }^{7}$ In short, it defines a set of patterns of and for a nation's behavior related to issues of war and peace. Further, it is derived from a nation's history, geography, and political culture, and represents the aggregate of attitudes and patterns of behavior of the most influential voices (i.e., the political and military elites). ${ }^{8}$ The field of strategic culture is interdisciplinary, with substantial contributions derived from the fields of business, psychology, sociology, anthropology, and international relations.

Closer examination suggests that a nation's strategic culture has many similarities with its military culture. Military culture depends on regional characteristics (geography, cultural affinity, and the institutional arrangement of the security complex) and the behavior of members of the military. In one difference between the two, strategic culture also depends on the complexity of state security parameters.

Events in Europe since the end of the Cold War have significantly changed the continent's strategic culture. Therefore, in order to define a strategic culture, it is necessary to determine each Balkan country's interests through the guiding principles of security policy, political system, security environment, historical experiences from past operations, and technological developments. During the Cold War, the former Yugoslav states were always in the (potential) line of fire between NATO and the Warsaw Pact, and were caught between the interests of these large collective security regimes.

6 Ken Booth, "The Concept of Strategic Culture Affirmed," in Strategic Power: USA/ USSR, ed. Carl G. Jacobsen (New York: St Martin's Press, 1990), 121.

7 Jeannie L. Johnson, "Strategic Culture: Refining the Theoretical Construct," report prepared for the Defense Threat Reduction Agency Advanced Systems and Concepts Office (McLean, VA: SAIC 2006), 5.

8 Ken Booth, Strategy and Ethnocentrism (New York: Holmes \& Meier Publishers, Inc., 1979), 121. 
After the collapse of the Warsaw Pact, the single solution pursued by the former Yugoslav states was joining NATO as a guarantee of security and stability for each country. Spanning the interests of the EU and NATO in the Balkan region, individual states' strategic and military cultures are mainly the result of variances in threat perceptions based upon an understanding of a state's either relative or absolute security. The use of the military by the Balkan states that have joined NATO is still shaped by these states' perceptions of the world and the norms that they adhere to. This has significant consequences for the path of defense transformation that states embark on.

\section{Gender Relations Within the Balkan Armies}

The era of security sector reform brought new changes related to gender issues in the armed forces in the Balkans. Inequitable distribution of ranks and the disproportion of men in the military boosted the use of men's "macho" style as a form of sexual discrimination, and perpetuated their underestimation of the physical and intellectual capacities of women. With the turn toward security sector reform, quotas were introduced for the admission of women into the military, which increased the quantity of female staff in the security forces, thus acting as an instrument of positive discrimination.

The increased presence of women in the military brought fresh perspectives to the previous conventional wisdom in the military. These new perspectives promoted greater tolerance and a softening of rigid relations in internal communication. Members of the military, through cooperation with NATO forces in the Balkans and through their participation in the missions of the Alliance, were witnesses to a different standard of behavior on the part of men toward their female colleagues within the military organization. Pressure was exerted on Balkan militaries more directly, through complaints of female peers, or through investigative reports by the media, who had a new opportunity to gain insight into sexual abuse and harassments of women by their own colleagues within the military.

Although women in the Balkans are often disrespected by men, since before the Second World War they have stood in Balkan society as symbols of family, sacrifice, and disobedience. These symbolic legacies still exist, so that changes in the image of women in Balkan society are still strongly resisted among the conservative part of the male population. Thus, male jokes at women's expense are considered as an integral part of the military subculture. The gestures of underestimation can be concealed behind expressions of sympathy, an inability to establish normal access and communication, and other practices. 


\section{Impact of Technology on Military Culture}

There are numerous changes in the world that work to enhance the pressures that civilian military culture places on the armed services. Technology has made impatience potentially an even greater problem than before. In the last several decades, telecommunications equipment has become so sophisticated and relatively inexpensive that it is now possible for anyone to file real-time stories and videos of combat, even if the individuals shooting the footage are far from the scene. In recent military activities in the Balkans, participants in the conflicts used digital cameras and video equipment to capture the events that were part of their everyday life. These records played an important role in helping to find the perpetrators of numerous genocides and various crimes against humanity, and most of them were recorded by the perpetrators of the acts themselves. The motives for creating these eerie documents lay in the need for self-actualization on the part of the perpetrators, and the desire to prove their quasi-heroism during military operations in the former Yugoslavia.

The second aspect of the use of technology within the military organization relates to improving systems of internal communication by using modern communication technologies. Ongoing contacts with NATO countries are enriching the technical vocabulary of the armies of the Balkan states, and parts of this terminology have become part of everyday communication.

The impact of military culture has to be limited to certain areas or groups, because it may produce a negative influence among the rest of the population, especially among the young. These categories of people often identify themselves as being members of the military, and try to display this affiliation through gestures, clothing, video games, etc. Sophisticated technology directs them toward aggression, and they are becoming increasingly intolerant.

\section{The "Military Brat" Subculture in the Balkans}

A military brat is a person whose parent or parents have served full-time in the armed forces during the person's childhood. Mary Edwards Wertsch said military brats have such values as idealism, antiracism, loyalty, patriotism, and honesty. ${ }^{9}$ The term is occasionally used in several English-speaking countries, namely Australia, Canada, New Zealand, and the United Kingdom ("pads' brats"), but it is in the United States in particular that the term "military brat" is used to refer to a collectively identifiable demographic (with extensive psychological research done on the group by the United

9 Rudi Williams, "Military Brats Are a Special Breed", U.S. Department of Defence, American Forces Press Services (20 August 2001); available at http://www.defense.gov/news/ newsarticle. aspx ?id=44766. 
States Department of Defense). ${ }^{10}$ The characteristics of this demographic group are shaped by frequent moves, the long-term absence of a parent, authoritarian family dynamics, strong patriarchal authority, threat of parental loss in war, and a militarized family unit. While non-military families share many of these same attributes, military culture is unique because of the tightly-knit communities that perceive these traits as normal. Military culture can have long-lasting effects on children. ${ }^{11}$ This is because the knowledge, experience, values, ideas, attitudes, skills, tastes, and techniques that are associated with the military can differ so widely from those of civilian culture. ${ }^{12}$ Military bases are miniature, self-contained, government-subsidized towns that promote conformity. ${ }^{13}$ Military families shop at the same stores, whose discounted merchandise is regulated to prevent unfair competition, so they can often end up wearing the same clothes and using the same products. ${ }^{14}$

This picture of the model of the social life of members of the U.S. military corresponds well to the former life of military personnel and their families as a separate demographic group in former SFR of Yugoslavia. ${ }^{15}$ The families of military personnel enjoyed numerous state benefits, such as opportunities to shop in stores exclusively for them at affordable prices, the opportunity to buy apartments under most favorable conditions, opportunities for summer vacations in the finest resorts owned by the military, etc. Mixed marriages were one of the characteristics of settlements that were built for the needs of military personnel. The children resulting from mixed marriages were raised in the Yugoslav spirit; there was no inter-ethnic hatred among them, and they expressed strong feelings of belonging to the state.

Although the disintegration of Yugoslavia has changed the demographic structure of military districts, military culture still continues to exist until today. Families who fled the military settlements and left to settle in other states-whether in one of the successor states of the SFRY or in other foreign countries-were replaced by the

10 Grace Clifton, "Making the Case for the BRAT (British Regiment Attached Traveller)," British Education Research Journal 30:3 (June 2004): 458.

11 Mary Edwards Wertsch, Military Brats: Legacies of Childhood inside the Fortress (New York: Harmony, 1991), 350.

12 USDA Army Youth Development Project, ed., Operation: Military Kids Ready, Set, Go!, Training Manual, $3^{\text {rd }}$ ed., "Chapter Four: Exploring Military Culture" (April 2007), 3-4; available at http://esd113.org/uploads/documents/studentsupport/Children\%20of\%20Military\%20Families/ReadySetGoManual/Chapter_4_Final.pdf.

13 Wertsch, Military Brats: Legacies of Childhood inside the Fortress, 34.

14 Lydia Sloan Cline, Today's Military Wife: Meeting the Challenges of Service Life (Mechanicsburg, PA: Stackpole Books, 1995), 26-30.

15 The author of this paper is a former officer of the Army of the Republic of Macedonia, and he spent his entire childhood on military bases as the son and grandson of employees in the Army of the Republic of Macedonia and the Yugoslav People's Army. 
families of military personnel who returned to their native countries. Most of their children were not born in the countries where their parents were born, so aside from domestic upbringing and family ties they did not have anything else that connected them with the new country. They were forced to quickly adapt to their new environment, and because of the distance that they had moved, continuing former friendships was just a fantasy.

Military culture experienced significant changes during the Balkan wars. Former neighbors in military settlements, who worked and lived together for years and whose children had grown up in the same environment, playing together and going to school together, suddenly came to view each other through the sights of a gun. Many of these families lost their loved ones. Families of military personnel were hostages of the nationalist policies of the new countries that emerged from the breakup of Yugoslavia.

\section{Measuring Public Confidence in the Army}

Although it is impossible to quantify military culture, measuring public opinion can be helpful in assessing the confidence the people place in the military relative to other state institutions. Such an assessment relates to public perception; measuring internal perceptions within the military remains a challenge for researchers in the future.

In a recent survey in the Republic of Macedonia, the army and religious institutions enjoy the highest confidence. ${ }^{16}$ Almost 11 percent of respondents reported to have the highest confidence in them among all social institutions. In another survey in 2004, most of the citizens trusted the army and police, while expressing insufficient confidence in the president, parliament, government, and judiciary. They do not place trust in trust any politicians. Confidence in the army was 69.9 percent, and that in the police was 58.8 percent. Only 26.5 percent of respondents said that they did not trust the Macedonian Army, while 38.5 percent expressed distrust in the police (see Table 1). ${ }^{17}$

16 The poll of 1162 respondents was conducted in February 2010 by the Institute "Dimitrija Cupovski" in Skopje, Republic of Macedonia. See http://sitel.com.mk/dnevnik/makedonija/anketa-najgolema-doverbata-vo-arm-i-verskite-zaednici.

17 This shows the results of a national telephone survey conducted on 21-22 December 2004 by the public opinion research agency "Maripannn." The poll was commissioned by the political party SDSM (Social-Democratic Union of Macedonia), and surveyed 1210 people from around the country. See "Gragjanite najmnogu im veruvaat na Armijata i Policijata," Utrinski Vesnik (16 October 2006); available at http://217.16.70.245/?pBroj=1 $668 \&$ stID $=28097 \& \mathrm{pR}=3$. 
THE QuARTERLY Journal

Table 1: Trust in the Public Services in Macedonia, 2008 ${ }^{18}$

\begin{tabular}{|l|l|c|}
\hline Institution & $\begin{array}{l}\text { Percentage of } \\
\text { Trust }\end{array}$ & Change \\
\hline President & 35.6 & $\leftrightarrow$ \\
\hline Government & 51 & $\uparrow \uparrow$ \\
\hline Parliament & 38.0 & $\uparrow \uparrow$ \\
\hline Judiciary & 21.2 & $\leftrightarrow$ \\
\hline Educational institutions & 65.8 & $\leftrightarrow$ \\
\hline Public utility companies & 38.8 & $\downarrow \downarrow$ \\
\hline Public health organizations & 55.1 & $\uparrow \uparrow$ \\
\hline Local self-government & 44.7 & $\leftrightarrow$ \\
\hline Army & 64.6 & $\leftrightarrow$ \\
\hline Police & 56.6 & $\leftrightarrow$ \\
\hline
\end{tabular}

\begin{tabular}{|c|c|c|}
\hline \multicolumn{3}{|c|}{ Legend } \\
\hline$\leftrightarrow$ & no or insignificant change & \multirow{7}{*}{$\begin{array}{l}\text { No or insignificant change }=0-3 \% \\
\text { Slight change }=3-5 \% \\
\text { Moderate change }=5-10 \% \\
\text { High change }=\text { over } 10 \%\end{array}$} \\
\hline$\uparrow$ & slight increase & \\
\hline$\downarrow$ & slight decrease & \\
\hline$\uparrow \uparrow$ & moderate increase & \\
\hline$\downarrow \downarrow$ & moderate decline & \\
\hline$\uparrow \uparrow \uparrow$ & large increase & \\
\hline$\downarrow \downarrow \downarrow$ & large decline & \\
\hline
\end{tabular}

In Serbia, a survey conducted by the Center for Free Elections and Democracy (CESID) in May 2009 of 4700 respondents showed that in the last year or so the level of trust that citizens have in the Serbian Armed Forces (SAF) has increased. The SAF is becoming an increasingly trustworthy institution, which information undoubtedly confirms that the state of affairs in SAF is now better than before. CESID was testing the trust of citizens in the president, government, parliament, legislature, police force, and NGOs. The results of the survey are reflected in Table $2 .{ }^{19}$

18 Sasho Klekovski, ed., Doverbata vo Gragjanskoto Opshtestvo (Skopje, Macedonia: Macedonian Center for International Cooperation, 2008), 7.

19 The research by CESID (Center for Free Elections and Democracy) in Belgrade (Serbia) on attitudes and habits of citizens was conducted across a sample of five thousand households in Serbia; the fieldwork was completed on 25 May 2009. "Trust in SAF on the Rise," Website of the Ministry of Defense of the Republic of Serbia (16 June 2009); available at http://www.mod.gov.rs/novi_eng.php?action=fullnews\&showcomments=1\&id=1618. 
Table 2: Trust in the Public Services in Serbia

\begin{tabular}{|c|c|c|c|c|c|c|c|}
\hline & & $\begin{array}{l}\text { Does not } \\
\text { know }\end{array}$ & $\begin{array}{l}\text { Does not } \\
\text { trust }\end{array}$ & $\begin{array}{l}\text { Mainly does } \\
\text { not trust }\end{array}$ & Neutral & $\begin{array}{l}\text { Mainly } \\
\text { trusts }\end{array}$ & Trusts \\
\hline \multirow{2}{*}{$\begin{array}{c}\text { Govern- } \\
\text { ment }\end{array}$} & 2008 & $32 \%$ & $36 \%$ & $12 \%$ & $14 \%$ & $4 \%$ & $2 \%$ \\
\cline { 2 - 8 } & 2009 & 24 & 40 & 14 & 15 & 5 & 2 \\
\hline \multirow{2}{*}{\begin{tabular}{c} 
President \\
\cline { 2 - 8 }
\end{tabular}} & 2008 & 30 & 29 & 9 & 14 & 9 & 9 \\
\hline \multirow{2}{*}{$\begin{array}{c}\text { Parlia- } \\
\text { ment }\end{array}$} & 2009 & 24 & 30 & 13 & 16 & 9 & 8 \\
\cline { 2 - 8 } & 2009 & 23 & 31 & 15 & 16 & 4 & 2 \\
\hline \multirow{2}{*}{ Judiciary } & 2008 & 28 & 33 & 16 & 10 & 3 & 2 \\
\cline { 2 - 8 } & 2009 & 25 & 35 & 17 & 17 & 4 & 3 \\
\hline \multirow{2}{*}{ Army } & 2008 & 29 & 20 & 13 & 18 & 12 & 9 \\
\cline { 2 - 8 } & 2009 & 23 & 17 & 12 & 20 & 15 & 12 \\
\hline \multirow{2}{*}{ Police } & 2008 & 26 & 26 & 14 & 19 & 8 & 6 \\
\cline { 2 - 8 } & 2009 & 22 & 24 & 15 & 19 & 12 & 8 \\
\hline \multirow{2}{*}{ Church } & 2008 & 23 & 11 & 6 & 15 & 17 & 29 \\
\cline { 2 - 8 } & 2009 & 21 & 13 & 8 & 18 & 17 & 22 \\
\hline \multirow{2}{*}{ NGOs } & 2008 & 34 & 31 & 9 & 14 & 8 & 4 \\
\cline { 2 - 8 } & 2009 & 29 & 35 & 12 & 14 & 7 & \\
\hline
\end{tabular}

Table 3: Trust in the Public Services in Croatia Compared with the EU

\begin{tabular}{|l|c|c|c|c|c|c|}
\hline & \multicolumn{2}{|c|}{ Trust } & \multicolumn{2}{c|}{ Does not trust } & \multicolumn{2}{c|}{ Does not know } \\
\hline & Croatia & EU 25 & Croatia & EU 25 & Croatia & EU 25 \\
\hline Police & $46 \%$ & $65 \%$ & $48 \%$ & $30 \%$ & $6 \%$ & $5 \%$ \\
\hline Army & 59 & 68 & 33 & 22 & 9 & 10 \\
\hline
\end{tabular}

Low confidence in the police in Croatia is the result of a large number of unsolved crimes, but also of the suspicion of corruption-this is in sharp contrast to the status of the police across the twenty-five member nations of the European Union, where it enjoys high confidence. The absence of scandals in the military is probably the reason that the level confidence in that institution is higher in Croatia (see Table 3). ${ }^{20}$

20 European Commission, Standard Eurobarometer 64, Public Opinion in European Union, TNS Opinion \& Social, National Report Croatia (Brussels: EC, Fall 2005), 12-13. 
Although citizens have much less contact with the military in their everyday life, yet their confidence in the army as a public institution is greatest. Through surveys, citizens measure the behavior of members of the military, their activity in protecting their national interests, and their freedom from scandals and corruption. The parameters that determine the confidence in the military mirror the positive values of military culture.

Following the collapse of the SFR Yugoslavia and the formation of the armies of the countries that emerged from it, many controversies arose associated with the existence of or the need for an army and its professionalism and neutrality as a model of determination in the new regional circumstances. The growing confidence among the Balkan publics in their armies increasingly confirms the necessity of the military as a key subject of the security system. The new standards and norms that armies have put in place for those wishing to join the military are progressively becoming a reality, and they are gradually bringing the armies up to NATO standards. This is illustrated by the membership of certain Balkan countries that have already joined NATO, as soon will be done by the rest of the Balkan states. Thus, military culture is identified with the values of the military alliance. The military is thus freed from all of the anomalies of its previous mode of operation, and is beginning to take its deserved place in society.

\section{Conclusion}

The Balkan countries are slowly returning to their rightful role within Europe. This time, the armies of the Balkan countries are the guarantee of peace and security, not in the region itself but also within larger international security coalitions. Balkan armies, through the process of Euro-Atlantic integration, have been obliged to adopt EU and NATO standards related to military behavior. Beyond the Balkans there are many challenges that have yet to provide an answer to the question of how best to direct and implement a military culture for civilian aims. Meeting these challenges will further clarify these states' vision of the appropriate form of civil-military relations.

The military forces currently display less constrained behavioral norms than previously, and they should be able to perform a wider range of military tasks, which will them to better exploit the weaknesses and to counter and defeat the strengths of their opponents. One of the aims of military culture is to determine whether the interaction of the threats posed by adversaries endanger the citizens, homeland security, society, material resources, and other vital interests of the state. The involvement of military culture in forming national and regional military strategies can help explain the occasional need for states to resort to a mercenary's professionalism as a rational option for military success or failure. Military culture theory provides a more powerful explanation of mercenaries' military performance. 
The new military culture has to be a product of peaceful behaviors and opinions created by the leaders, experts, and institutional members of the security system. The conclusions and outputs have to be distributed to the whole population with the principal aim or protecting the state and its values that are guaranteed under the national constitutions. Military culture should be based on a constructed value system that will be embodied in a code of ethics and the rules of the services. Military culture should be a product of the democratic values of civil society and state efforts to maintain peace and stability in the Balkan countries. The norms of military culture have to isolate and punish violent and illegal activities on the part of military staff.

Using a sophisticated military culture based on reasonable proactive behavior is an indicator of the presence of professionalism in the military, and in the security sector more generally. That conversion leads to the creation of a contemporary and sophisticated army with the intention to achieve the following attributes: openness to criticism from the general public and security experts, the highest levels of transparency, and an ability to keep up with modern security trends and current threats. A unique military culture rooted in the military code of ethics, the arts of the military profession, a robust security culture, a clearly articulated security policy, and a rational set of state interests has to be a goal for each state in the Balkans if they are to achieve full membership in the Euro-Atlantic community. 


\section{Bibliography}

Booth, Ken. "The Concept of Strategic Culture Affirmed." In Strategic Power: USA/ USSR. New York: St Martin's Press, 1990.

Booth, Ken. Strategy and Ethnocentrism. New York: Holmes \& Meier Publishers, Inc, 1979.

Cassidy, Robert M. "The British Army and Counterinsurgency: The Salience of Military Culture." Military Review 85, no. 3 (2005).

Clifton, Grace. "Making the Case for the BRAT (British Regiment Attached Traveller)." British Education Research Journal 30, no. 3 (2004): 458.

Cline, Lydia Sloan. Today's Military Wife: Meeting the Challenges of Service Life. Mechanicsburg, PA: Stackpole Books, 1995.

Johnson, Jeannie L.. Strategic Culture: Refining the Theoretical Construct In Defense Threat Reduction Agency Advanced Systems and Concepts Office . McLean, VA: SAIC, 2006.

Murray, Williamson. "Military Culture Does Matter." FPRI Wire 7, no. 2 (1999).

Stojanovski, Trpe. Policijata vo Demokratskoto Opshtestvo. Shtip, Macedonia, 1997.

Vujaklija, Milan. Leksikon Stranih Reci i Izraza. Belgrade, Serbia: Prosveta, 1980.

Wertsch, Mary Edwards. Military Brats: Legacies of Childhood inside the Fortress . New York: Harmony, 1991. 